\title{
Studying the Effect of Corruption on Income Per-capita Level in an IV Estimation in Developing countries
}

\author{
By Hoda Hassaballa ${ }^{1}$
}

\begin{abstract}
Income per-capita is a measure of economic well-being. Through its effect on economic development, it can indirectly affect sustainable development. Hence, it is essential to study the determinants of Income per-capita Level. Recently, corruption level has played an influential role in determining income per-capita. However, theoretically and empirically its effect is still debatable. Besides the traditional determinants of income per-capita, the effect of corruption on Income percapita level is examined in a sample of developing countries between1996-2013. There is a potential endogeneity problem that arises from the two way relationship between corruption and income per capita levels which threatens internal validity. Accordingly, an instrumental variable (IV) in a two stage least squares (2SLS) estimation is conducted. The results indicate its presence. Furthermore, the results show that corruption is a significant determinant of income per-capita level in developing countries. Policy implications to promote governance which in turn affect sustainable development are also given.
\end{abstract}

Keywords: Income per-capita, corruption, IV estimation and developing countries. JEL: H8, O1

\section{Introduction}

Over the years, income per-capita was commonly used to describe the wellbeing of individuals in a specific period of time. This was usually done without putting into consideration the inter-temporal dimension in which sustainable development can be also affected by income per-capita level. Income per-capita level can indirectly affect sustainable development through its effect on economic development. ${ }^{1}$ This can be through the effect of income per-capita on education, health, migration and sanitation levels. Having low levels of income per-capita is more likely to reduce the individuals' access to high levels of education and knowledge. In addition, it deprives individuals from better nutrition which negatively affect their health status and productivity as well as it encourages migration from the country whenever possible. Also, low income percapita is associated with poor environmental conditions such as poor sanitation, high levels of pollution and lack of access to clean water. ${ }^{2}$ In particular, the literature is rich in tracing the effect of low levels of income per-capita on pollution emissions level as illustrated by the Environmental Kuznets Inverted U hypothesis (EKC) (Dasgupta et al.,

\footnotetext{
1 See the United Nations website for more details at

http://www.un.org/esa/sustdev/natlinfo/indicators/methodology_sheets/econ_development/gdp_percapita.pdf

${ }^{2}$ For more information see http://www.worldbank.org/depweb/english/modules/economic/gnp/print.html

${ }^{1}$ Lecturer of Economics The Department of Economics, The British University in Egypt Suez Desert Road, El Sherouk City, Cairo, Egypt. Postal Code: 11837. Email: hoda.hassaballa@bue.edu.eg, Mobile: +201001101974; Fax: +202 23653980.
} 
2002 and Cialani, 2007). Putting all these effects into consideration will result in adverse effects on sustainable development. Hence, it is crucial to study the determinants of Income per-capita level.

Moreover, corruption level has increased massively. This phenomenon is present in both the developed as well as the developing world. However, it is more evident in developing countries. For instance, the transparency international list of the top 10 corrupt countries in 2014 include Somalia , North Korea, Sudan, Afghanistan, South Sudan , Iraq, Turkmenistan, Uzbekistan, Eritrea and Libya which are all developing countries. ${ }^{3}$ Recently, corruption level has played an influential role in determining income per capita level. However, theoretically and empirically its effect is still debatable. The debate is present in two levels: the nature and the direction of corruption-Income per capita relationship. Hence, the objective of this research paper is to investigate the effect of corruption on income per-capita level in developing countries. This is examined in an IV estimation over the period 1996-2013. The use of IV in a 2 stage least squares (2SLS) is the chosen estimation technique due to the presence of a potential endogeneity problem that arises from the two way relationship between corruption and income per capita levels. This is because corruption affects and is affected by income per-capita level.

The rest of the paper is organized as follows: Section 2 shows the theoretical and empirical debates present in the literature. Section 3 presents the empirical model and results. Finally, conclusion and policy implications are provided in section 4.

\section{Literature Review}

On the theoretical level, the relationship between corruption and income percapita is indistinct. There is an ongoing debate in the literature on the nature and the direction of corruption-income relationship. With respect to the nature of the relationship, there are two opposing views, namely, efficiency enhancing view and efficiency reducing view (Rehman and Naveed, 2007). Efficiency enhancing view states that corruption has positive effect on economic growth which in turn increases income per capita (Leff, 1964; Huntington, 1968; Acemoglu and Verdier, 1998). According to 'the efficient grease' hypothesis, corruption results into more efficiency (Mustapha, 2014). This is because it acts as a lubricant that motivates bureaucrats to be more productive and allows investors to escape time-consuming regulations or other transactional costs (Pak Hung Mo, 2001). In line with that, da Silva et al.( 2001) highlighted the importance of the economic theory of bribe in studying corruptionincome relationship. Bureaucrats receive bribes and firms accept paying them as both are after maximizing their utilities.

Nevertheless, the opposing view believes that corruption has a negative effect on the economy (Kaufman and Wei, 1998; Aidt, 2009 and Mauro,1995). Rehman and Naveed (2007) illustrated that through what they considered the 'efficiency reducing' strand in which corruption has a harmful effect on efficiency. This is usually associated with demotivating investors to invest resulting into loss of productivity (Pak Hung Mo, 2001). In addition, corruption increases the gap between the rich and the poor and destroys any

${ }^{3}$ http://www.transparency.org/cpi2014/results\#myAnchor1 
incentive to innovate. Furthermore, corruption increases the size of uncertainties and political instability which hinder economic growth and development (da Silva et al., 2001). In sum, one can consider corruption effect on income as a rent seeking problem. According to Gyimah-Brempong (2002), corruption results into misallocation of resources, loss of innovation, the shift from productive activities to rent seeking ones, and incurring additional costs of production that in turn will discourage investment. Da Silva et al. (2001) also highlighted that the degree of corruption varies with the type of institutions structure and the number of regulations.

In between these two opposing views, a third school of thought evolved. This school deviates a little bit from the rather rigid ideology of positive effect of corruption on income. This is through tracing the effect of corruption on allocative efficiency. According to Rehman and Naveed (2007), allocative efficiency can be realized in the presence of corruption. This is because although bureaucrats ignores the 'principle of competitive bidding' and grants contracts to the biggest bidder, it is usually the case that those who can afford to pay the highest bribes are the ones with the lowest cost.

On the empirical level, the debate is still pronounced. For instance, Li and Wu (2010) showed in their study of pooled 65 countries that trust offsets the negative effect of corruption on income. In addition, Blackburn and Forgues-Puccio (2009) studied the reason behind the uneven effect of corruption in various countries in a dynamic general equilibrium model. Their results highlighted that countries with well-organized corruption network will result in lower levels bribes and more rates of growth. Furthermore, Rock et al (2004) studied the relationship between corruption and economic growth in four different corruption datasets. Their results showed that corruption slows down growth in developing countries but increases it in newly industrialized large East Asian countries.

Opposite to this, Mauro (1995) studied the relationship between investment and corruption in 58 countries. His results highlighted that corruption has a negative effect on investment which in-turn affects the economy negatively. In line with that, Kaufman and Wei (1998) examined the effect of bribes payment on time and cost of capital. Their result opposed the efficient grease hypothesis as they found that those who pay bribes spend more time in negotiating with bureaucrats at a higher cost of capital. Furthermore, Aidt (2009) showed that growth and corruption exhibit a strong negative relationship. The same result was also reached by Igwike, Hussain, and Noman (2012) in their study. They showed that there is an inverse relationship between corruption and economic development measured by annual growth rate of the gross domestic product.

With respect to the direction of corruption-income relationship, the debate is still present on both the theoretical and the empirical levels. At one hand, corruption affects income as discussed earlier. Hence, the direction of relationship goes from corruption to income. On the other hand, income can also affect corruption which results into the ongoing debate of whether corruption-income exhibit a one way or a two way relationship. According to Seldadyo and de Haan (2006), income per capita is one of the main determinants of corruption. The economic logic behind this is that corruption varies according to income's level. There are many studies that confirm this finding (Damania et al., 2004; Persson and Tabellini, 2003; and van Rijckeghem and Weder,1997). However, Kaufmann et al. (1999) and Hall and Jones (1999) are skeptical 
about the causal relationship between corruption and income. Some studies showed that income level has a positive effect on corruption such as Braun and Di Tella (2004) and Frechette (2001). Nevertheless, there are more evidences that show that income has a negative effect on corruption such the case of Kunicova and Ackerman (2005), Lederman et al. (2005), Braun and Di Tella (2004), Chang and Golden (2004), Damania et al. (2004) and many others. Cole (2007) studied the relationship between income, corruption and the environment. He acknowledged in his research work the presence of a two way relationship between income and corruption. For that, he used an IV estimation to avoid problems associated with endogeneity.

Hence, the theoretical and empirical reviews confirm that corruption-income debates are not yet finalized. Therefore, this research paper constitutes a step forward to have a better understanding of this debatable issue in the field of economics.

\section{The Empirical Model}

The empirical model examines the effect of corruption on income per-capita level based on the work of Cole (2007). A panel data model is used to investigate the effect of corruption, fixed capital, human capital, population growth, trade openness and the rate of inflation on income per capita level in developing countries over the period 1996-2013 for which data is available. ${ }^{4}$

\subsection{The Econometric Approach}

The following fixed effect panel data model with homogenous slopes is considered:

$$
\log G D P_{i t}=\alpha \log C O R_{i t}+\beta^{\prime} \log X_{i t}+\lambda_{i}+\varepsilon_{i t}
$$

For a country $\mathrm{i}$ at time t, GDP is GDP per capita; COR is the measure of corruption level; $\mathrm{X}$ is a vector of explanatory variables which includes determinants of GDP per capita other than corruption; $\lambda$ is the fixed effect dummy variable for individual unobserved effects and $\varepsilon$ is the error term.

Using panel data increases the sample size which results into a better estimation. This is of extreme importance in the presence of a large number of explanatory variables. In addition, it improves the power of the test statistics and saves degrees of freedom. Accordingly, panel data is preferred than cross section data or time series analysis.

\subsection{The Choice of Variables}

There are several measures used to evaluate corruption level. For instance, there is a measure of corruption created by the International Country risk guide which is used by some researches such as Cole (2007). In addition, there is the control of corruption

4 The list of countries includes Bolivia, Cameroon, Columbia, Ecuador, Egypt, India, Indonesia, Malaysia, Mexico, Nigeria, South Africa and Turkey. 
indicator constructed by the World Bank which is used before by many researchers such as Wei (1997) and Zhou (2007). However, this research paper uses the corruption perception index (CPI) computed by Transparency International Organization which is used by many researchers such as Tavares (2004) and Bakare (2011). The reason is that CPI is a good measure of public sector corruption on the aggregate level (Rohwer, 2009). ${ }^{5}$ The CPI scores the level of corruption perceived in different countries between 0-10 where 0 indicates very high level of corruption and 10 indicates low levels of corruption. Hence, the greater the CPI is, the less the level of corruption will be. Since the review of the literature indicated that the relationship between corruption and income per-capita is indistinct, the following results are expected: A positive coefficient of CPI indicates that the greater the CPI is, the lower the level of corruption will be and the more the income per capita will be. Thus, there is a negative relationship between corruption level and income per capita which moves in line with efficiency reducing view. On the other hand, if the coefficient of CPI is negative, this indicates that the higher the CPI is, the lower the level of corruption will be and the lower the per capita income will be. Thus, there is a positive relationship between corruption level and income per capita which illustrates the case of efficiency enhancing view.

In addition to level of corruption, other traditional determinants of income percapita are used. These are fixed capital, human capital, population growth, trade openness and the rate of inflation. ${ }^{6}$ For fixed effect capital, the gross fixed capital formation is used. The coefficient of this explanatory variable is expected to be positive. This is because the more capital is available, the higher the income per capita will be as suggested by exogenous growth theories, Solow model (1956) and many others.

For human capital, it has been proven that higher level of education is the most important element of human capital (OECD, 1998; World Bank, 1998). Accordingly, secondary school enrollment ratio is used in this research to measure human capital. This variable was used before by several researchers such as Root and Ahmed (1979), Schneider and Frey (1985) and Noorbakhsh et al (2001). Higher human capital will result into more growth as suggested by the endogenous growth theories. It is expected then to have a positive relationship between secondary school enrolment and income per capita level.

Population effect on GDP per capita is measured by the rate of growth of the population. It is expected to have a negative relationship between population growth and income per-capita level. The logic behind this is the more the population is, the less the share of each individual in national income will be. Also, population growth puts limitation on expansion of savings, foreign exchange and human resources which affects economic growth negatively (SAVAŞ, 2008). Sometimes, population growth can contribute positively to economic growth if it fosters production, innovation, competition and technological progress. Hence, this relationship is also indefinite.

Trade openness computed as the sum of exports and imports over GDP can also affect economic growth. This is because trade promotes competition, innovation

\footnotetext{
${ }^{5}$ For more information, visit cpi.transparency.org.

${ }^{6}$ These traditional determinants are used by many researchers such as Cole (2007), Mankiw et al.(1992), Levine and Zervos (1993) and Levine and Renelt (1992).
} 
and efficiency. It also results into realizing benefits of economies of scale as a result of expanding domestic markets. Sachs and Warner (1995); Edwards (1998); Frankel and Romer (1999) and Lee et al. (2004) showed that high economic growth is associated with more outward-oriented countries. Also, Freund and Bolaky (2008) and Chang et al. (2009) also confirmed that trade openness has a positive effect on income provided that it is complemented by other policies. It is expected then, to have a positive relationship between trade openness and income per-capita.

Finally, the rate of inflation is expected to have a negative effect on economic growth. There are many logical explanation for this among which is that inflation reduces investment and efficiency as suggested by Andres and Hernando (1997). However, the most interesting one is that inflation acts as a tax on human capital which in turn decreases the marginal product of human capital. Hence, there will be less utilization rate of human capital resulting into low rates of return to capital as well as lower economic growth (Basu et al., 2009). Accordingly, it is expected to have a negative relationship between rate of inflation and income per-capita. It is rare to have a positive relationship between rate of inflation and economic growth. This may occur if the rise in nominal interest rate is less than the rise in rate of inflation resulting into a decrease in real interest rate. A decrease in real interest rate will encourage investment which increases economic growth.

The sources of data are the World Development Indicators and the Transparency International Organization databases. Missing data were calculated through the use of linear interpolation.

\subsection{Model Estimation}

To examine the effect of the level of corruption on income per-capita level, a static panel data model is used. The sample studied includes 12 developing countries over the period 1996-2013 for which data is available. Hausman test between random effects and fixed effects models was conducted which resulted into a rejection of random effects model. Accordingly, a fixed effects panel data model is used as shown in equation (1). There is a potential endogeneity problem that arises from the two way relationship between corruption and income per capita levels as explained in the literature review which threatens internal validity. To tackle this issue, an IV in a two stage least squares (2SLS) estimation is conducted. It is worth mentioning that IV estimation is less sensitive to any misspecification and yields consistent estimators. However, it results in biased coefficients since it is not as efficient as OLS especially in the case of weak instruments. The first step is to find a valid instrument ( $Z$ ) for corruption such that it is exogenous and relevant as expressed by these two conditions respectively

i. $\quad \operatorname{Cov}(Z, \varepsilon)=0$

ii. $\quad \operatorname{Cov}(Z, \operatorname{Corr}) \neq 0$

It is important to highlight that the first condition is difficult to be tested due to unavailability of the unbiased estimator $\varepsilon$. Hence, researchers follow their economic intuition regarding this matter. However, the second condition can be tested. Testing for the relevance of the instrumental variable to satisfy condition (ii) is done through running an auxiliary regression in which corruption is regressed on its instrument and all other determinants of income per-capita level. If the coefficient of the instrument is 
significant, then this instrument is relevant. This is the first-stage regression. Following this, income per capita is regressed on all explanatory variables in which they are instrumented on themselves except for corruption which is instrumented on Z in a 2SLS estimation. A Wu-Hausman test was also used to test for endogeneity since in its absence, OLS and IV yield consistent estimators; however, they are inefficient in the case of IV only.

It is important to highlight that the number of internet users per 100 people is used as an instrument $(\mathrm{Z})$ of corruption. Information availability through the internet results into a more transparent society since it provides individuals with information related to their government's practices and regulation as suggested by Wu (2011). Not only had this, but also Bellver and Kaufmann (2005) showed that it supplies users with social, political or economic information in a timely and at the same time less costly manner. Another advantage of the internet access is that usually the information is supplied by individuals resulting into higher degree of transparency. Also, Stiglitz (2002) showed that transparency is a precondition for good governance and low levels of corruption (Norris and Zinnbauer, 2002). Empirically, many researchers such as Schroth and Sharma (2003), Roberts (2006) and WU (2011) found strong correlation between access to the internet and corruption levels. ${ }^{7}$ Hence, there is sufficient evidence that the number of internet users can be used as an instrument of corruption. ${ }^{8}$

Hence, equation (1) shows that at time $t$ in country i, log GDP per capita (Y) is regressed in a 2SLS estimation on log of corruption instrumented by the number of internet users (per 100 people) (IU), log of gross fixed capital (GF), log of gross secondary school enrolment (Sec), Log of population growth (Pop), log of trade openness (TO) and log of rate of inflation (INF).

\subsection{The Empirical Results}

Table (1) shows the results of the auxiliary regression in which corruption is regressed on its instrument (the number of internet users per 100 people) and all other explanatory variables of income per-capita. The results of this first-stage regression indicate that the number of internet users can be a relevant instrument of corruption level as its coefficient is found significant and positive. However, there is a potential for being a weak instrument as its t-value is less than 3.2 and its corresponding p-value is greater than 0.0016. Possible explanations for this are the small number of cross sections as suggested by Cai et al. (2010) or the weak-moderate association between the number of internet users and income per capita as indicated in footnote 8.

To remedy such a problem, lagged corruption level is used as an instrument for current corruption level. The results shown in table (2) confirmed that lagged corruption level is a relevant instrument since its t-value is greater than 3.2 and its corresponding $\mathrm{p}$-value is less than 0.0016 .

\footnotetext{
$7 \mathrm{Wu}(2011)$ in his thesis entitled "Internet Technology and Impact on Corruption" found that at 1\% level of significance, the internet access is a significant determinant of corruption level.

${ }^{8}$ It is important to highlight that the number of internet users can reflect technical progress effect, thereby it could have a direct effect on income per capita. This could threaten its validity as an IV. However, the correlation between the number of internet users and GDP per capita is 0.4 which is considered weakmoderate correlation.
} 
Table (1)

First Stage Estimation of Corruption Level (Instrument: Number of Internet users)

\begin{tabular}{|l|l|}
\hline Dependent Variable: Log COR & Coefficients \\
\hline C & -0.456996 \\
& $(-0.860761)$ \\
Log GFS & $\mathbf{0 . 0 2 6 6 0 6}$ \\
& $\mathbf{( 2 . 8 4 9 1 7 9 ) *}$ \\
Log SEC & $\mathbf{0 . 2 6 1 7 7 6}$ \\
& $\mathbf{( 4 . 2 1 2 8 1 0 ) *}$ \\
Log POP & $\mathbf{0 . 2 4 4 2 2 0}$ \\
& $\mathbf{( 2 . 2 5 9 7 0 1 ) * *}$ \\
Log TRADE & 0.165817 \\
& $(1.553697)$ \\
Log INFL & -0.091718 \\
& $(-1.442407)$ \\
R-Squared & 0.005630 \\
& $(0.362206)$ \\
\hline t-values are in parenthesis, $*$ significant at $1 \%$ Level and** significant at $5 \%$ level) & 0.841805 \\
\hline
\end{tabular}

Table (2)

First Stage Estimation of Corruption Level (Instrument: Lagged Corruption Level)

\begin{tabular}{|l|l|}
\hline Dependent Variable: Log COR & Coefficients \\
\hline C & -0.667963 \\
& $(-1.987354)$ \\
Log CPI(-1) & $\mathbf{0 . 4 8 5 6 7 2}$ \\
& $\mathbf{( 8 . 7 7 2 0 6 2 ) *}$ \\
Log SEC & $\mathbf{0 . 1 1 8 7 1 0}$ \\
& $\mathbf{( 2 . 1 9 8 8 9 8 ) *}$ \\
Log POP & $\mathbf{0 . 2 2 3 8 3 0}$ \\
& $(\mathbf{3 . 3 2 8 5 6 6 ) *}$ \\
Log TRADE & -0.033273 \\
& $(-0.391944)$ \\
Log INFL & $-0.001925)$ \\
& $(-0.039300)$ \\
R-Squared & -0.009428 \\
& $(-0.780575)$ \\
\hline
\end{tabular}

t-values are in parenthesis, * significant at 1\% Level.

Table (3) shows the results of three estimations: First: The results of an OLS estimation of equation (1) in which corruption is treated as an exogenous variable in model (Y1). 
Second: The results of a 2SLS estimation in which corruption is instrumented by the number of internet users per 100 people in model (Y2). Third: The results of a 2SLS estimation in which corruption is instrumented by the lagged corruption level in model (Y3). It is important to highlight that models (Y2) and (Y3) are estimated after correcting for heteroskedasticity through White correction and GLS Weights respectively.

The empirical results show that corruption level is a significant determinant of income per-capita in all the three models. Also, trade and inflation are found insignificant in all the three models. Model Y (1) suffers from a potential endogeneity problem. Accordingly, corruption level is instrumented on the number of internet users per 100 people in model Y (2). Two pitfalls are found in model Y (2): Only corruption and population are found significant in such regression. In addition, the t-value of coefficient of the corruption level indicated that the number of internet users per 100 people is a weak instrument of corruption. For that corruption level is instrumented on its lagged value in model Y (3).

In model Y (3), the coefficients of all explanatory variables are found significant with the exception of trade and inflation. The coefficient of corruption level is found significant and positive which indicates that the greater the CPI is, the lower the level of corruption will be and the more the income per-capita will be. Thus, there is a negative relationship between corruption level and income per capita which moves in line with efficiency reducing view. The coefficient of GFS is found significant and positive. This shows that the more capital is available, the higher the income per-capita will be as suggested by exogenous growth theories, Solow model and many others.

Table (3)

The Effect of Corruption on Income Per-capita Level

\begin{tabular}{|l|l|l|l|}
\hline $\begin{array}{l}\text { Dependent Variable: } \\
\text { Log GDP }\end{array}$ & Y1 & Y2 & Y3 \\
\hline C & $\mathbf{5 . 2 6 5 6 6}$ & $\mathbf{7 . 8 7 6 5 2 2}$ & $\mathbf{5 . 3 6 6 0 0 8}$ \\
& $(\mathbf{1 8 . 4 6 6 7 1 ) *}$ & $\mathbf{( 7 . 0 5 9 8 6 2 ) *}$ & $\mathbf{( 1 8 . 3 2 0 5 6 ) *}$ \\
\hline Log CPI & $\mathbf{0 . 2 1 9 0 1 7}$ & $\mathbf{2 . 0 5 0 2 7 9}$ & $\mathbf{0 . 3 3 0 8 9 6}$ \\
& $\mathbf{( 4 . 6 2 8 0 7 1 ) *}$ & $\mathbf{( 2 . 6 8 5 6 6 3 ) *}$ & $\mathbf{( 4 . 5 6 0 2 6 1 ) *}$ \\
\hline Log GFS & $\mathbf{0 . 1 7 0 5 5 4}$ & -0.303498 & $\mathbf{0 . 1 6 4 9 5 4}$ \\
& $\mathbf{( 3 . 8 8 0 3 1 9 ) *}$ & $(-1.428446)$ & $\mathbf{( 3 . 7 2 0 6 4 4 ) *}$ \\
\hline Log SEC & $\mathbf{0 . 4 0 1 2 0 3}$ & -0.444012 & $\mathbf{0 . 3 5 1 7 3 9}$ \\
& $\mathbf{( 7 . 1 1 1 0 9 6 ) *}$ & $(-1.388616)$ & $\mathbf{( 6 . 0 5 9 2 4 9 ) *}$ \\
\hline Log POP & $\mathbf{- 0 . 4 1 3 6 7 1}$ & $\mathbf{- 0 . 6 2 7 3 6 0}$ & $\mathbf{- 0 . 3 0 3 3 1 3}$ \\
& $\mathbf{( - 5 . 7 6 3 8 1 2 ) *}$ & $\mathbf{( - 3 . 0 1 6 8 0 6 ) *}$ & $\mathbf{( - 5 . 1 9 5 5 2 ) *}$ \\
\hline Log TRADE & 0.054429 & 0.153935 & 0.050668 \\
& $(1.285213)$ & $(1.259475)$ & $(1.436483)$ \\
\hline Log INFL & 0.019376 & 0.020629 & -0.005652 \\
& $(1.853728)$ & $(0.681821)$ & $(-0.689292)$ \\
\hline R-Squared & 0.989379 & 0.909053 & 0.993278 \\
& & & \\
\hline
\end{tabular}

t-values are in parenthesis, * significant at $1 \%$ Level.

In addition, the coefficient of secondary school enrolment is found significant and positive. This indicates that higher human capital results into more growth as suggested 
by the endogenous growth theories. Finally, the coefficient of population is found significant and negative. This shows that the more the population is, the less the share of each individual in national income will be. Also, population growth puts limitation on expansion of savings, foreign exchange and human resources which affects economic growth negatively. IV estimation results will be consistent but inefficient in the absence of endogeneity. For that Wu-Hausman test for endogeneity is conducted.

Applying Wu-Hausman test for endogeneity for models (Y2) and (Y3) confirmed that corruption level is endogenous since the residual $\boldsymbol{V}$ of the first stage regression and the error term of the following OLS regression $\mathcal{E}$ are correlated. This is because the coefficient of the residual of the first stage regression $\delta$ was found significant as indicated by the t-test ( $t$ values are equal to--11.98071 and -2.313943 for Y (2) and Y (3) models respectively). It is important to highlight that in the absence of homoskedasticity, Wu-Hausman test yields invalid results. For that, GLS weights are used.

$$
\operatorname{LogGDP}_{i t}=\alpha \log C O R_{i t}+\beta^{\prime} \log X_{i t}+\delta v_{i t}+\lambda_{i}+\varepsilon_{i t}
$$

\section{Conclusion and Policy Implications}

This research paper studied the effect of corruption level on income per-capita level. A static panel data model is used. The sample studied includes 12 developing countries over the period 1996-2013. An IV with a 2SLS estimation was used in which corruption level was instrumented by the number of internet users per 100 people and its lagged value in two separate regressions. The former instrument was proven to be a weak instrument which could be altered in the case of large number of cross sections. This problem was absent in the case of the latter instrument. The estimation results highlighted that corruption level is a significant determinant of income per-capita level since there exists a negative relationship between corruption and income per-capita. In addition, gross fixed capita, human capital and population affect income per-capita levels. Contrary to this, the coefficients of rate of inflation and trade were found insignificant. Designing suitable policy implications that incorporates these results is very essential to promote sustainable development. These policy implications are:

1. Strong enforcement of law is a must to fight corruption. This could be through adopting a comprehensive regulatory system of inspection, monitoring and punishments. Having clear cut criteria with all the needed specifications in written laws and regulations is important. Delivering this information to the public is also essential since some people violate the law without knowing that they are doing so. In addition, it will be meaningless if these laws and regulations are not complied with. For that, penalties and incentives are to be used to promote compliance.

2. It is important to have equal stand with no exceptions what-so-ever regarding penalties imposed on corrupt individuals. Otherwise, it will represent a typical case of corruption.

3. Disclose information about the proven corrupt individuals to the public through the mass media. This is to form a kind of a public threat to the corrupt individuals to think twice before committing any corrupt acts. 
4. The mass media as well as schools should teach children all the ethics needed to constitute a healthy living society that is based on fairness, equal rights, freedom and equity but with strong governance.

5. Strengthen the role of civil society and non-governmental organizations in fighting corruption. This should be complemented by democratic governments that willingly accept the active participation of civil society and are ready to eliminate any obstacles that may hinder their efforts in fighting corruption.

6. Close all possible channels of corruption in the government administration. This can be through eliminating or at least minimizing the role of individuals in decision making. Nowadays, there is a massive revolution in the use of technology, computers and communication. Accordingly, it is very essential to spread the use of such automated systematic techniques in providing services to the public. This in turn will increase efficiency and minimize corruption level.

7. Increase the wages of workers in the public sector to allow them to live a decent life to minimize the likely occurrence of accepting bribes and performing corrupt acts.

8. Provide a healthy economic environment that encourages investment and promotes investing in human capital in specific to foster more economic growth. This can be achieved through minimizing the procedures and regulations needed to start a new business. In addition, the provision of economic incentives in the form of tax breaks or subsidies can encourage foreign direct investment into a country. Above all, it is of vital importance to preserve both economic and political stability since these are precondition for promoting foreign direct investment. With respect to human capital, improving the efficiency of the educational system at schools is a corner stone. Moreover, the provision of a continuous training system for employee is very important to upgrade their old skills and to enable them to acquire new skills that best suit their institutions demand.

9. Reduce the massive rise in population growth due to its negative effect on income per-capita level. This can be done through spreading awareness, making birth control measures available and at low costs as well as increasing women empowerment.

These are few suggestions to reduce corruption level, promote investment in both physical and human capital and reduce population growth rates which in turn will increase income per capita level. As stated earlier, having higher income per-capita level is essential due to its indirect effect on sustainable development. For that, increasing income per-capita level should be the top priority of all developing countries.

\section{References}

Acemoglu, D and Verdier, T. (1998) Property rights, corruption and the allocation of talent: a general equilibrium approach, The Economic Journal,108, pp. 1381-1403.

Aidt, T. (2009) Corruption, institutions and economic development, Oxford Review of Economic Policy, 25, pp. 271-291.

Andres, J and Hernando, I. (1997) Does inflation harm economic growth? evidence for the OECD, NBER Working Paper, No. 6062.

Bakare, A. (2011). The crowding-out effects of corruption in Nigeria: an empirical study. Journal of Business Management and Economics, 2, 59-68.

Basu, P., Gillman, M. and Pearlman, J. (2009) Inflation, human capital and tobin's q, Centre for Dynamic Macroeconomic Analysis in its series of CDMA Conference Paper Series, number 0904. 
Bellver, A. and Kaufmann, D. (2005) Transparenting transparency: initial empirics and policy applications, The World Bank Paper, : http://ssrn.com/abstract=808664 [Accessed at 9/99/2015]

Blackburn, K. and Forgues-Puccio, G.F.(2009) Why is corruption less harmful in some countries than in others? Journal of Economic Behavior and Organization, 72, pp. 797-810.

Braun, M. and Di Tella, R. (2004) Inflation, inflation variability, and corruption. Economics and Politics, 16, pp. $77-100$.

Cai, Z., Fang, Y. and Li, H. (2012) Weak instrumental variables models for longitudinal data, Econometric Reviews, 31, pp. 361-389.

Chang, E. and Golden, M. (2004) Electoral systems, district magnitude and corruption. Paper presented at the 2003 annual meeting of the American Political Science Association, August 28-31.

Chang R., Kaltani, L. and Loayza, N.V. (2009) Openness can be good for growth: the role of policy complementarities, Journal of Development Economics, 90, pp. 33-49.

Cialani, C. (2007) Economic growth and environmental quality: An econometric and a decomposition analysis, Management of Environmental Quality: An International Journal, 18, pp. 568 - 577.

Cole, M. A.( 2007) Corruption, income and the environment: an empirical analysis, Ecological Economics, 62, pp.637-647.

Da Silva, M., Garcia, F. and Bandeira, A. (2001) How does corruption hurt growth? Evidences about the Effects of Corruption on Factors Productivity and Per Capita Income. São Paulo :Fundação Getúlio Vargas, Escola de Administração de Empresas de São Paulo.

Damania, R.,Fredriksson, P., and Mani, M. ( 2004) The persistence of corruption and regulatory compliance failures: theory and evidence, Public Choice, 121, pp. 363-390.

Dasgupta, S., Laplante, B., Wang, H. and Wheeler, D. (2002) Confronting the Environmental Kuznets Curve, The Journal of Economic Perspectives, 16, pp. 147-168.

Edwards, S. (1998) Openness, productivity and growth: what do we really know? Economic Journal, 108, pp. 383-398.

Frankel, J. and Romer, D. (1999) Does trade cause growth? American Economic Review, 89, pp. 379-399.

Frechette, G. (2001) A panel data analysis of the time-varying determinants of corruption. Paper presented at the EPCS.

Freund, C. and Bolaky, B. (2008) Trade, regulations, and income, Journal of Development Economics, 87, pp. 309-321.

Gyimah-Brempong (2002) Corruption, economic growth and income inequality in Africa, Economics of Governance, 3, pp. 183-209.

Hall, R. and Jones, C. (1999) Why do some Countries produce so much more output per worker than others. Quarterly Journal of Economics,114, pp. 83-116.

Huntington, S. P. (1968) Political order in changing societies. New Haven: Yale University press.

Igwike, R., Hussain, E. and Noman, A (2012) The impact of corruption on economic development: a panel data analysis. Social \& Cultural Issues, (Topic) 02/2012.

Kaufmann, D. and Wei, S (1998) Does grease money speed up the wheels of commerce? NBER Working Paper No. 7093.

Kaufmann, D., Kraay, A., and Mastruzzi, M. (1999) Governance Matters. World Bank Policy Research Working Paper 2196.

Kunicova, J. and Ackerman, S. (2005) Electoral rules and constitutional structures as constraints on corruption. British Journal of Political Science, 35, pp. 573-606.

Lederman, D., Loayza, N., and Soares, R. (2005) Accountability and corruption: political institutions matter. Economics and Politics. 17, pp. 1-35.

Lee, H., Ricci, L., and Rigobon, R. (2004) Once again, is openness good for growth? NBER Working Papers. Cambridge: NBER.

Leff, N. (1964) Economic development through bureaucratic corruption, American Behavioral Scientist, 8, pp. 8-14.

Levine, R. and Renelt, D. (1992) A sensitivity analysis of cross-country growth regressions, American Economy Review, 82, pp. 942-963.

Levine, R. and Zervos, S. (1993) what we have learned about policy and growth from cross-country regressions, American Economy Review, 83, pp. 426-430.

Li, S. and WU, J. (2010) Why some countries thrive despite corruption: The role of trust in the corruptionefficiency relationship. Review of International Political Economy, 17, pp. 129-154. 
Mankiw, N., Romer, D. and Weil, D. (1992) A contribution to the empirics of economic growth, The Quarterly Journal of Economics, 107, pp. 407-437.

Mauro, P. (1995) Corruption and growth. Quarterly Journal of Economics. 110, pp. 681-712.

Mustapha, N. (2014) The impact of corruption on GDP per capita, Journal of Eastern European and Central Asian Research, 1, pp.1-5.

Noorbakhsh, F., Paloni, A. and Youssef, A. (2001) Human capital and FDI inflows to developing countries: new empirical evidence, World Development, 29, pp. 1593-1610.

Norris, P., \& Zinnbauer, D. (2002). Giving voice to the voiceless: good governance, human development and mass communications. Human development report 2002.

OECD. (1998). Human capital investment: an international comparison. Paris: OECD Centre for Educational Research and Innovation.

Pak Hung Mo (2001) Corruption and economic growth, Journal of Comparative Economics, 29, pp. 66-79.

Persson, T. and Tabellini, G. (2003) The Economic Effects of Constitutions. Cambridge.: MIT Press.

Rehman, H. and Naveed, A. (2007) Determinants of corruption and its relation to GDP (A panel study), Journal of Political Studies, 12, pp. 27-59.

Roberts, A. (2006) Blacked out: Government secrecy in the information age, New York: Cambridge University Press.

Rock, M. and Bonnett, H. (2004) The comparative politics of corruption: accounting for the East Asian paradox in empirical studies of corruption, growth and investment, World Development, 32, pp. 999-1017.

Rohwer, A. (2009) Measuring corruption: a comparison between the transparency international's corruption perceptions index and the World Bank's worldwide governance indicators, Ifo Institute for Economic Research at the University of Munich, 7, pp.42-52.

Root, F. and Ahmed, A.(1979) Empirical determinants of manufacturing direct foreign investment in developing countries Economic Development and Cultural Change, 27, pp. 751-767.

Sachs, J. D. and Warner, A. (1995) Economic reform and the process of global Integration, Brookings Papers on Economic Activity, 1, pp.1-118.

SAVAŞ, B. (2008) The relationship between population and economic growth: empirical evidence from the Central Asian Economies, http://www.usak.org.tr/dosyalar/dergi/vdLzqZ8KkgADbpdNOlj7fazny9hvCN.pdf [Accessed $22 / 6 / 2015]$

Schndeider, F. and Frey, B.S.(1985) Economic and political determinants of foreign direct investment. World Development, 13, pp. 161-175.

Schroth, P.W. and Sharma, P. (2003)Transnational law and technology as potential forces against corruption, Management Decision, 41, pp. 296-303.

Seldadyo, H., and de Haan, J. (2006) The determinants of corruption: a

literature survey and new evidence, Working paper, University of Groningen.

Solow, R. (1956) A contribution to the theory of economic growth, The Quarterly Journal of Economics, 70, pp. 65-94.

Stiglitz, J.E. (2002). On liberty, the right to know and public discourse: The role of transparency in public life. In: M. Gibney, Editor, Globalizing rights, Oxford: Oxford University Press.

Tavares, A. (2004). The socio-cultural and political-economic causes of corruption: a cross-country analysis. Working Paper in Economics (wpaper:192004): Universidade de Aveiro. https://ideas.repec.org/p/ave/wpaper/192004.html [Accessed 5/5/2015]

The United Nations website. Available from

http://www.un.org/esa/sustdev/natlinfo/indicators/methodology_sheets/econ_development/gdp_percapi ta.pdf. [Accessed 11/6/2015].

The World Bank Website. Available from http://www.worldbank.org/depweb/english/modules/economic/gnp/print.html.

[Accessed 11/6/2015]

The World Bank. (1998). Knowledge for development: World development report 1998/1999. New York: Oxford University Press

The World Development Indicators. Available from

http://data.worldbank.org/data-catalog/world-development-indicators 
[Accessed 6/6/2015]

Transparency International Organization (http://www.transparency.org) and http://cpi.transparency.org [Accessed 11/8/2015]

Van Rijckeghem, C. and Weder, B. (1997) Corruption and the rate of temptation: do low wages in the civil service cause corruption?IMF Working Paper WP/97/73.

Wei, Shang-Jin. (1997). Why is corruption so much more taxing than tax:? arbitrariness kills. NBER Working Paper (working paper 6255). www.nber.org/papers/w6255. [Accessed 5/5/2015]

Wu, W. (2011), Internet Technology and Its Impact on Corruption, A Senior Honors Thesis, University of California, San Diego.

Zhou, Y. (2007). An empirical study of the relationship between corruption and FDI: with sample selection error correction. www.etsg.org/ETSG2007/papers/zhou.pdf [Accessed 1/4/2015] 